\title{
How does Rumah Pintar Manage to Facilitate Community to Learn?
}

\author{
Jajat S Ardiwinata, Viena Rusmiati Hasanah, Sardin, Katiah \\ Department of Nonformal Education \\ Faculty of Science of Education \\ University Pendidikan Indonesia \\ viena@upi.edu
}

\begin{abstract}
This research aims to find out role of management in the facilitation of learning for community in Rumah Pintar Al Barokah. The research employed descriptive method and qualitative approach. In order to gain data, three types of techniques were used including interview, observation and documents study. This research was done to five people as the subjects. The results showed that there were some strategies used by Rumah Pintar to facilitate community learning, namely social animation activity, mediation and negotiation, supports provision, consensus building, group facilitation, skills and sources usage and organization. This research concludes that the management has successfully facilitated community to prepare their learning facilities through Rumah Pintar Al Barokah. In this place, community gains knowledge and additional activities in developing their learning needs.
\end{abstract}

Keywords- facilitate community learning, Management of Rumah Pintar

\section{INTRODUCTION}

One of community institutions aiming at improving societies learning interest, potentials, children intelligence and technology introduction through many learning centers is Rumah Pintar. In this institution, societies are developed and empowered by using potential local as the basis so that they can grow their entrepreneurship abilities to improve the level of families lives. Role of management leadership becomes pivotal since management is center of management of an institution to attain its goals [1].

Management of Rumah Pintar can be considered as community service worker because this place serves community education. As community service worker, management has roles and skills in line with position or situation. Community service worker are faced with several roles as their responsibilities. In this case, there are four categories of community service worker roles, including facilitative, educational, representational and technical roles [2]. Each category of community service role has own tasks expected to be carried out in certain situations. In the initial stage, the role of management is to facilitate in the development of many programs and activities in community. It has motivated the research to explore in depth on how management can facilitate community to learn?

\section{LITERATURE REVIEW}

A role taken by an individual will be different according to his profession and position. Role of management in rumah pintar can be considered as community service since this place serves education community where management functions and is responsible for community education and empowerment. There are four categories of community service roles including facilitative, educational, representational, and technical roles [3]. Each role has several tasks (abilities to master) by community service worker.

Role or skill to facilitate task involves many activities including social animation activity, mediation and negotiation, supports provision, consensus building, group facilitation, many sources and skills usage and various events organizations. Activities including in the facilitating task can explain as follows in details. 1) social animation refers to ability to inspire, to activate, to stimulate, to drive and motivate others to act. Someone serves as community service worker must be able to make others participate in various community activities; 2) mediation and negotiation activities are ability to listen, to understand from many perspectives, to analyze, to formulate same interests of all parties and consensus, and to transfer those abilities to the community themselves; 3) supports provision means that community service workers must be able to provide supports for people involved in various community structures and activities. It covers affirming community, recognizing and admitting their values and their contributions. Community service workers must always give support, provide themselves when they need to discuss about something or to ask many questions and so on; 4) Consensus activity refers to agreement as a result of expansion of mediation and negotiation tasks. Building consensus means to face values difference, interests, and competition without using conflict approach; 5) group facilitation activity refers to managing many actions and group activities. A community service worker should be able to identify and make use of many different skills and resources with communities and groups; 6) organization activity is to encourage the implementation of activities with communities. This organization activity can make effective the empowerment and can increase work awareness of community members [4]. 


\section{METODOLOGY}

This research employed qualitative approach and descriptive method. The subjects involved in the research were five people including three management people of Rumah Pintar, namely head, center management and tutor as well as two learners. The subjects were determined based on purposive sampling by considering that those subjects are people who understand service activities and condition of institution. The data were collected by using interview, observation and document study.

\section{RESULT}

Social animation activity was conducted by management by providing stimulation and motivation to learners or communities to learn and to help learn one another in Rumah Pintar. Management of Rumah Pintar Al Barokah has an ability to invite people to act through the implementation of socialization program. This activity involved learners and community. Apart from that, management conducted interpersonal communication in giving social animation.

Someone who functions as community service worker should enable others to participate in various community activities. Mediation and negotiation activities done by management was carried out, among others, when there was a project of Rumah Pintar Al Barokah building. In this case, communities involving religious figures and local communities figures were in request of finance for the building. To answer it, management conducted mediation activity, discussing separately to provide explanation to each figure and then in one time, these two figures were invited to get explanation from management regarding building project. Within community, finance and project aspects done in the area became the problems and thus transparancies on the reports were needed. In this case, management played their roles by mediating and negotiating for overcoming conflict occured in the community.

Supports provision involves activities to inspire, to activate, to stimulate, to drive and motivate others to act. It was done by management of Rumah Pintar to assist community to learn in centers provided in Rumah Pintar. For early childhood, playing center with many learning and playing facilities for children are provided and supported. When the targets are mothers or housewives, kriya center is filled with many activites for developing skills that can support skills and can increase community economies. When the targets are teenagers, Rumah Pintar could access often computer center to improve motivation on technology knowledge and education. Similarly, stage center is also provided with facilities to develop interests and abilities in musics, vocals and drama. Supports provision done by management aims at enabling society to learn and create something so that they can develop and improve. A community service worker plays a role on providing supports for people involved in many types of community structures and activities embracing affirming citizens, recognizing, and admitting their values and their contributions, providing supports and providing themselves when community needs to discuss or to ask.
A management person as a community service worker builds consensus; an agreement that is a result of expansion of mediation and negotiation. One of the activities done by management to build consensus among management person, tutor, and learner was in the decision making of learning or activity schedule.
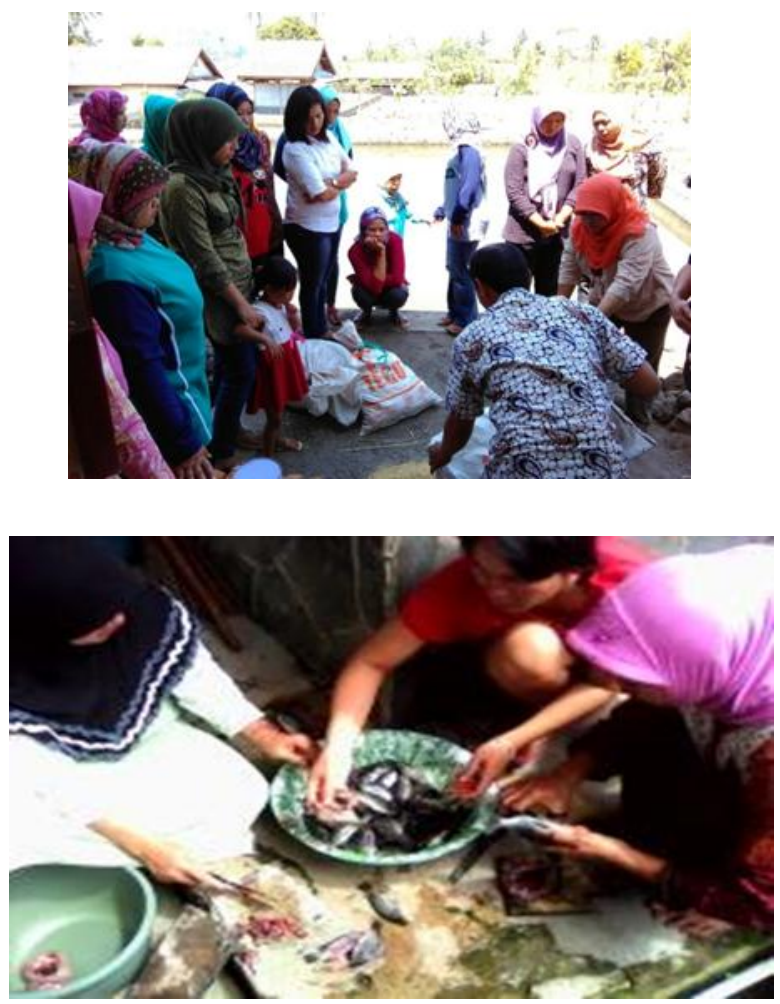

Activity on the facilitation done by management of Rumah Pintar Al Barokah

Group facilitation was done by management of Rumah Pintar Al Barokah by offering and inviting as well as gathering groups with lack of learning structures and infrastructures to join and use those in Rumah Pintar. Several groups have ever been facilitated including Qasidah (religious chant of Arabic sung to the rhythm of gambus) of groups, Early childhood education, and children of Islamic school in the level of Junior high.

Management of Rumah Pintar made use of many skills and resources by inviting, facilitating and improving identified abilities. The activity of making use of natural resources such as handmade products such as key chains and brooches from the shell of berenuk (calabash) fruits was done by collaborating with citizens in the provision of raw materials.

Another activity is to make students of Junior islamic school play tambourine to become peer tutors in the center of stage of Rumah Pintar Al Barokah. Management of Rumah Pintar has implemented the making use of many skills and resources in line with the consideration that a community service worker should be able to identify and make use of many skills and resources existed in the community or groups. 
Community service worker should be sensitive to resources and facilities that have not been used optimally.
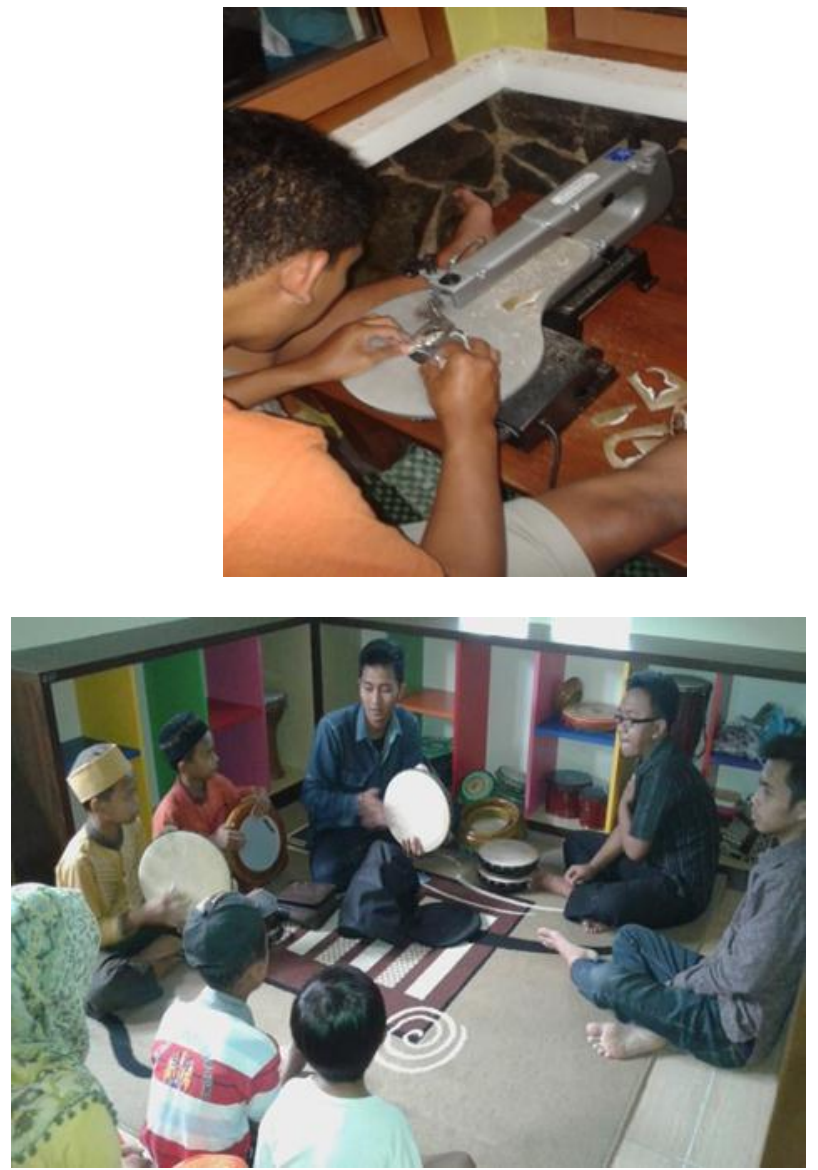

Activity of the making use of community potential and production.

Management of Rumah Pintar Al Barokah always encourage and well organize the implementation of activities the community done by learners and other communities. Management is in cooperation with and contributes to several activities either in the forms of power or thoughts. Organizing refers to encouraging the implementation of activities together with community. Organization activity can make effective the empowerment and the increase of working awareness of community members.

\section{CONCLUSION}

\section{A. Conclusion and Suggestion}

- Conclusion

Facilitation activity to community and learners in general has been conducted by the management of Rumah Pintar Al Barokah. Most activities of social animation, mediation and negotiation, supports, consensus building, group facilitation, the making use various skills and resources, and activities management. Activities of management in facilitating community to learn in Rumah Pintar was done as one of the means to empower society and further to build another effort to build involvement of community independence.

\section{- Suggestion}

This research suggest that management of Rumah Pintar Al Barokah should optimize their performance and should minimize restrictions or obstacles faced in the management through the improvement of management capacity, by managing finances so that management tasks or activities in technical activities can be fulfilled and by doing follow-up and fostering program for partners for the sake of maintenance. Furthermore, for future researchers who are also interested in community learning activities organized by Community Learning Center or similar institution such as Rumah Pintar, this study suggests that researchers can further investigate aspects encouraging community to participae more intensively in education activity hold by the institution.

\section{REFERENCES}

[1] Sudjana. (2010). Manajemen Program Pendidikan Untuk Pendidikan Nonformal. Bandung: Falah Production.

[2] Ife, J. dan Frank, T. (2008). Alternatif Pengembangan Masyarakat di Era Globalisasi: Community Development. Yogyakarta: Pustaka Pelajar.

[3] Ife, J. dan Frank, T. (2008). Alternatif Pengembangan Masyarakat di Era Globalisasi: Community Development. Yogyakarta: Pustaka Pelajar.

[4] Djohani, R. (2003). Partisipasi, Pemberdayaan dan Demokratisas Komunitas. Bandung: Studio Driya Media. 